\title{
Chemical and Physical Hazards in Different Small
}

\section{Workshops Activities}

\author{
Khaled F. El-Said*
}

\begin{abstract}
Workers in informal small-scale industries (SSI) in developing countries involved in welding, spray painting, woodwork, and metalwork are exposed to various hazards with consequent risk to health. The present study was to assess occupational exposures to chemical and physical hazards among workers in small workshops. Three different industrial activities were selected for this study. These activities are: car repairing, welding, and wood processing. Inside the selected workshops, different physical hazards as noise, heat stress, illumination, and dust as well as air pollutants of carbon monoxide (CO) nitrogen dioxide, (NO2), sulphur dioxide (SO2), and benzene were measured at the same two periods of the day (morning and evening) using calibrated devices. Analyzed data revealed high significant increase in the selected areas in the levels of noise, thermal stress, illumination, and dust during morning and evening exposure between as compared to the control area in the selected areas respectively. Only for $\mathrm{NO}_{2}$, levels of the other gases pollutants inside all exposed workshops are higher than those inside the control workshops. In conclusion, the workers at the studied industries were exposed to potential occupational hazards. These findings should be considered as $\mathrm{s}$ a preventive measures for monitoring and application of control strategies in such workplace environment
\end{abstract}

\section{INTRODUCTION}

Small-scale industries (SSI) have existed

as an informal sector since the pre-colonial

times making various tools, ornaments and

cooking utensils without regard to

occupational hazards. Small-scale

industries are determined by the number of persons employed which are less than 10

persons on the average. It represents a major sector for economic investment that brings a lot of benefits to the country as well as the individuals. ${ }^{(1,2)}$

Workers in informal small-scale

\footnotetext{
*Occupational Hygiene, Occupational Health Department, High Institute of Public Health, Alexandria ,Egypt.
} 
industries (SSI) in developing countries involved in welding. Spray painting, woodwork, and metalwork workes are exposed to various hazards with consequent risk to health. ${ }^{(3)}$

Workers in SSI are exposed to a variety of work-related hazards, where they are not using protective equipment and had health complaints perceived to be related to their work. Workers and employers were both aware of occupational and environmental health hazards, but absence of a clear policy on the informal sector and the lack of permanent workplaces do not encourage investment in occupational health and safety.(4)

Although the Small-scale industries include a wide variety of industrial activities, the most important and common types are car repairing, metal processing, and wood processing activities. (3,4) $^{2}$

Workers in automobile repair shop are at high risk of exposure to noise, vibration, heat stress, and radiation. Haematological changes, skin diseases, cancer, musculoskeletal, psychological stress, chronic poising, and irritation are the most health disorders among workers in automobile repair shop.(5)

Industrial welding has been associated historically with lung diseases, and current welding techniques continue to produce many potential exposures to particulates and gases as carbon monoxide (CO), nitrogen dioxide (NO2) sulphur Dioxide (SO2), and bezyene. Moreover, some studies suggest that these workers are at risk of serious respiratory, neurological, and reproductive effects. $(6,7)$

Industries that have a high risk of wood-dust exposure include sawmills, dimension mills, furniture industries, cabinet makers, and carpenters. ${ }^{(8)}$ The main sources of harmful dust emission at the workplace are during technological processes. ${ }^{(9)}$ The present study was conducted to shad lights on occupational exposures to chemical and physical 
hazards among workers in small

workshops

\section{MATERIAL AND METHODS}

Three industrial activities were selected for this study. These activities are: car repairing, welding, and wood processing. From each activity, three workshops were selected.The selected control site means the same type of activity without the presence of sources of exposures as in the other three shops.

Inside the selected workshops, different physical hazards as noise, heat stress, and illumination were measured at the same two periods of the day (morning and evening).

During the present study, noise levels were assessed by the TES-1352A(10) programmable and calibrated sound level Meter. Heat stress index (Wet Bulb Globe Temperature $\mathrm{WBGT}^{(10)}$ was used to determine the heat stress levels at selected workshops. The illumination levels were determined by a calibrated light meter
(TES 1336A)(10). Dust or total suspended particulates (TSP) was collected inside the selected workshops by calibrated personal samplers (Staplex® PST-2X Personal Air Sampler).(11)

Different air pollutants were measured inside all selected workshops by the standard methods and instruments. The selected air pollutants were total suspended particulates (TSP), carbon monoxide (CO), nitrogen dioxide $\left(\mathrm{NO}_{2}\right)$, sulfur dioxide $\left(\mathrm{SO}_{2}\right)$, and benzene. Levels of these pollutants were assessed also at two different periods; morning and evening. The MIRAN 205B Series SapphIRe-XL Portable Ambient Air Analyzer was used for assessment of the selected gaseous air pollutants. ${ }^{(12)}$

\section{Statistical Analysis}

Results of the collected data were statistically analyzed using the SPSS program version16.0 software. Descriptive Statistics and test of significant (ANOVA) were also used for studying the 
significance differences between the efficient control measures at the worksite studied factors.

and or the proper use of appropriate

\section{RESULTS AND DISCUSSION}

personal protective equipment.

Workers in these rapidly developing However, personal protective countries are be exposed to excessive equipment and exposure control measures amounts of both physical and chemical are rarely used at many worksites, and are pollutants. Small size industries workers, in given little importance and preference by particular, are routinely exposed to dust, gases, fumes, and heat, amongst other pollutants.

Occupational exposures to heat, wet bulb temperatures, illumination as well illumination and noise are unavoidable in as level of indoor gases as $\mathrm{SO} 2, \mathrm{NO} 2$, and the small size industries, but these $\mathrm{CO}$ were taken during the normal operation exposures could be minimized through and on a normal working day .

Table 1: Descriptive statistics of Physical hazards in car repairing workshops

\begin{tabular}{|l|c|c|c|c|c|c|c|c|}
\hline Time & \multicolumn{4}{|c|}{ Morning } & \multicolumn{5}{c|}{ Evening } \\
\hline Place & \multicolumn{4}{|c|}{ IN } & \multicolumn{4}{c|}{ IN } \\
\hline Parameter & Heat & Noise & Light & Dust & Heat & Noise & Light & Dust \\
\hline Mean & 33.9 & 86.29 & 176.25 & 2.21 & 35.42 & 77.025 & 157.15 & 1.91 \\
\hline SD & 2.03 & 16.42 & 3.19 & 1.01 & 3.48 & 14.36 & 16.10 & 0.62 \\
\hline Range & 6 & 45.2 & 10 & 2.45 & 9.3 & 34.7 & 39.3 & 1.53 \\
\hline Min & 30.8 & 63.8 & 171 & 1.07 & 30.8 & 62.6 & 141.7 & 1.07 \\
\hline Max & 36.8 & 109 & 181 & 3.52 & 40.1 & 97.3 & 181 & 2.6 \\
\hline
\end{tabular}


Table (2): Comparison of the levels of physical Hazards in car repairing workshop

\begin{tabular}{|l|c|c|}
\hline \multirow{2}{*}{ Survey Factor } & \multicolumn{2}{|c|}{ P-Value } \\
\cline { 2 - 3 } & Morning & Evening \\
\hline Heat & $0.0002^{\star \star}$ & $0.0002^{\star \star}$ \\
\hline Noise & $0.0003^{\star \star}$ & $0.0001^{\star \star}$ \\
\hline Light & $0.0005^{\star *}$ & $0.0003^{\star \star}$ \\
\hline Dust & $0.0001^{* \star}$ & $0.0008^{\star *}$ \\
\hline
\end{tabular}

${ }^{\star *} p<0.01$

In Tables 1 and 2, in car repairing, there there is no significant differences in the are significant high increase levels of level of noise (morning) and control. In Car noise exposure (evening), thermal stress, repairing, the level of dust in morning and illumination, and dust exposure between night are below the standard level placed exposure and control area respectively and by ACGIH of $0.1-3.3 \mathrm{mg} / \mathrm{m}^{3}{ }^{(15)}$

Table (3): Descriptive statistics of physical hazards in metal processing workshops

\begin{tabular}{|l|c|c|c|c|c|c|c|c|}
\hline time & \multicolumn{4}{|c|}{ Morning } & \multicolumn{4}{c|}{ Evening } \\
\hline Place & \multicolumn{3}{|c|}{ IN } & \multicolumn{4}{c|}{ IN } \\
\hline parameter & Heat & Noise & Light & Dust & Heat & Noise & Light & Dust \\
\hline Mean & 31.03 & 89.26 & 158.52 & 2.03 & 29.9 & 85.44 & 114.88 & 3.14 \\
\hline SD & 1.07 & 14.18 & 12.24 & 0.63 & 1.15 & 10.99 & 47 & 0.53 \\
\hline Range & 3.5 & 37.1 & 28.4 & 2.07 & 3.1 & 26.9 & 109.8 & 1.65 \\
\hline Min & 28.8 & 70.3 & 146.8 & 1.38 & 28.6 & 70.3 & 65.4 & 2.03 \\
\hline Max & 32.3 & 107.4 & 175.2 & 3.45 & 31.7 & 97.2 & 175.2 & 3.68 \\
\hline
\end{tabular}


Table (4): Comparison of the levels of physical Hazards in Metal Processing Workshop

\begin{tabular}{|c|c|c|}
\hline \multirow{2}{*}{ Survey Factor } & Morning & P-Value \\
\cline { 2 - 3 } & & $0.001^{\star \star}$ \\
\hline Heat & $0.0042^{\star \star}$ & $0.02^{\star}$ \\
\hline Noise & 31.12 & $0.002^{\star \star}$ \\
\hline Light & $0.001^{\star}$ & $0.00325^{\star \star}$ \\
\hline Dust & $0.0015^{\star \star}$ & \\
\hline
\end{tabular}

${ }^{\star *} \mathrm{P}<0.01$

In Tables 3 and 4 , there are significant length of the workday during the general high increase in the level of noise, thermal work shift was 10-12 hours, depending on stress, illumination, and dust in the morning the production targets. In addition, some of and evening exposure between exposure the workers worked overtime.(15) and control area in metal Processing However, average level of noise in the workshop .Although the overall mean noise metal processing represent high level of level at the selected area was $>85 \mathrm{~dB}$ in noise exposure which does not comply almost all working areas, none of the with the international standard (OSHA) of workers used earmuffs or plugs, or even a $85 \mathrm{~dB}^{(15)}$.

helmet with ear protection. The average 
Table (5): Descriptive statistics of physical has and in wood processing workshops

\begin{tabular}{|l|c|c|c|c|c|c|c|c|}
\hline time & \multicolumn{4}{|c|}{ Morning } & \multicolumn{4}{c|}{ Evening } \\
\hline Place & \multicolumn{4}{|c|}{ IN } & \multicolumn{4}{c|}{ IN } \\
\hline parameter & Heat & Noise & Light & Dust & Heat & Noise & Light & Dust \\
\hline Mean & 35.05 & 81.52 & 253.33 & 3.87 & 32.94 & 80.20 & 157.5 & 4.46 \\
\hline SD & 4.43 & 81.52 & 168.71 & 1.97 & 2.63 & 11.61 & 15.54 & 4.46 \\
\hline Range & 11.5 & 30.4 & 350 & 5.78 & 7.4 & 31.7 & 40 & 5.61 \\
\hline Min & 29.8 & 65.5 & 135 & 1.04 & 29.8 & 65.5 & 135 & 1.04 \\
\hline Max & 41.3 & 95.9 & 485 & 6.82 & 37.2 & 97.2 & 175 & 6.65 \\
\hline
\end{tabular}

Table (6): Comparison of the levels of physical Hazards in Wood Processing Workshop

\begin{tabular}{|c|c|c|}
\hline \multirow[b]{2}{*}{ Survey Factor } & \multicolumn{2}{|c|}{ P-Value } \\
\hline & Morning & Evening \\
\hline Heat & $0.02^{*}$ & $0.0025^{\star \star}$ \\
\hline Noise & $0.0009^{* *}$ & $0.0020^{\star *}$ \\
\hline Light & $0.0009^{* *}$ & $0.0001^{* *}$ \\
\hline Dust & $0.006^{\star *}$ & $0.014^{* *}$ \\
\hline
\end{tabular}

In Tables 5 and 6, there are highly underline the need for interventions to significant differences in the level of noise, reduce the risk for the development of thermal stress, illumination, and dust in NIHL (Noise Induce Hearing Loss) among morning and evening exposure between Wood processing workers. ${ }^{(16,17)}$ exposure and control area in wood In workers in car repairing, wood processing workshop processing and metal processing are

Workers in car repairing, wood exposed to low level of illumination in the processing, and metal processing are morning and night which are below the occupationally exposed to high levels of OSHA standard level of 500 Lux which in noise, and present high rates of noiseturn can cause serious health effects as induced hearing loss. These findings glare, cathartic, and eye strain and these 
finding are in accordance with recent studies $^{(18)}$

In wood processing workshops the level of dust in the morning and night are higher than the standard level placed by ACGIH of 0.1-3.3 ppm which in turn could have serious health illness among exposed workers in comparison with control. It is clear that exposures to physical hazards can result in serious health disorders among workers in such exposure.(18)
Wood processing workshop represents the highest level of dust exposures among exposed workers in comparison with control workers in relation to the car repairing, metal processing workshop. (19)

The highest level of CO $(12.71 \pm 5.4$ ppm) was found inside the wood processing workshops during the evening period. The lowest one $(4.9 \pm 0.89 \mathrm{ppm})$ was obtained during the morning period inside the car repairing workshops as shown in table 7.

Table (7): Levels of $\mathrm{CO}$ inside the three selected workshops activities

\begin{tabular}{|l|c|c|c|c|c|c|}
\hline Time & \multicolumn{3}{|c|}{ Morning } & \multicolumn{3}{c|}{ Evening } \\
\hline Workshop & $\begin{array}{c}\text { Car } \\
\text { Repairing }\end{array}$ & $\begin{array}{c}\text { Metal } \\
\text { processing }\end{array}$ & $\begin{array}{c}\text { Wood } \\
\text { processing }\end{array}$ & $\begin{array}{c}\text { Car } \\
\text { Repairing }\end{array}$ & $\begin{array}{c}\text { Metal } \\
\text { processing }\end{array}$ & $\begin{array}{c}\text { Wood } \\
\text { processing }\end{array}$ \\
\hline Mean & 4.9 & 7.81 & 7.15 & 6.49 & 7.49 & 12.71 \\
\hline SD & 0.89 & 6.59 & 2.34 & 1.56 & 1.85 & 5.40 \\
\hline Range & 2.4 & 15.5 & 6.6 & 3.8 & 5.2 & 14.04 \\
\hline Min & 3.5 & 1.3 & 4.3 & 5.1 & 5 & 6.1 \\
\hline Max & 5.9 & 16.8 & 10.9 & 8.9 & 10.2 & 20.14 \\
\hline
\end{tabular}

The highest level of $\mathrm{NO}_{2} \quad$ ppm) was obtained during the morning $(0.58 \pm 0.48 \mathrm{ppm})$ was found inside the period inside wood processing workshops wood processing workshops during the as shown in table 8. evening period. The lowest one $(0.28 \pm 0.19$ 
Table (8): $\mathrm{NO}_{2}$ levels inside the three selected workshops activities

\begin{tabular}{|c|c|c|c|c|c|c|}
\hline Time & \multicolumn{3}{|c|}{ Morning } & \multicolumn{3}{c|}{ Evening } \\
\hline Workshop & $\begin{array}{c}\text { Car } \\
\text { Repairing }\end{array}$ & $\begin{array}{c}\text { Metal } \\
\text { processing }\end{array}$ & $\begin{array}{c}\text { Wood } \\
\text { processing }\end{array}$ & $\begin{array}{c}\text { Car } \\
\text { Repairing }\end{array}$ & $\begin{array}{c}\text { Metal } \\
\text { processing }\end{array}$ & $\begin{array}{c}\text { Wood } \\
\text { processing }\end{array}$ \\
\hline Mean & 0.54 & 0.29 & 0.28 & 0.48 & 0.35 & 0.58 \\
\hline SD & 0.27 & 0.25 & 0.19 & 0.26 & 0.2 & 0.48 \\
\hline Range & 0.8 & 0.8 & 0.6 & 0.8 & 0.7 & 1.4 \\
\hline Min & 0.1 & 0 & 0 & 0.1 & 0.1 & 0 \\
\hline Max & 0.9 & 0.8 & 0.6 & 0.9 & 0.8 & 1.4 \\
\hline
\end{tabular}

The highest level of $\mathrm{SO}_{2}(29.97 \pm 11.73$ period. The lowest value $(7.84 \pm 3.18 \mathrm{ppm})$ ppm) was found inside the wood was obtained during the morning period processing workshops during the evening inside metal processing work shop as shown in table 9 .

Table (9): $\mathrm{SO}_{2}$ levels inside the three selected workshops activities

\begin{tabular}{|c|c|c|c|c|c|c|}
\hline Time & \multicolumn{3}{|c|}{ Morning } & \multicolumn{3}{c|}{ Evening } \\
\hline Workshop & $\begin{array}{c}\text { Car } \\
\text { Repairing }\end{array}$ & $\begin{array}{c}\text { Metal } \\
\text { processing }\end{array}$ & $\begin{array}{c}\text { Wood } \\
\text { processing }\end{array}$ & $\begin{array}{c}\text { Car } \\
\text { Repairing }\end{array}$ & $\begin{array}{c}\text { Metal } \\
\text { processing }\end{array}$ & $\begin{array}{c}\text { Wood } \\
\text { processing }\end{array}$ \\
\hline Mean & 8.91 & 7.48 & 16.45 & 8.65 & 10.72 & 29.97 \\
\hline SD & 0.65 & 3.18 & 1.44 & 1.52 & 2.16 & 11.73 \\
\hline Range & 1.64 & 7.47 & 4.37 & 3.46 & 5.26 & 29.52 \\
\hline Min & 8.08 & 3.81 & 14.3 & 6.62 & 8.4 & 17.55 \\
\hline Max & 9.66 & 11.28 & 18.67 & 10.08 & 13.66 & 47.07 \\
\hline
\end{tabular}

The highest level of benzene $(16.73 \pm 2.77 \quad$ lowest one $(7.38 \pm 9.05 \mathrm{ppm})$ was obtained ppm) was found inside the car repairing during the morning period inside metal workshops during the morning period. The processing work shop as shown in table 10. 
Table (10): Benzene levels inside the three selected workshops activities

\begin{tabular}{|l|c|c|c|c|c|c|}
\hline Time & \multicolumn{3}{|c|}{ Morning } & \multicolumn{3}{c|}{ Evening } \\
\hline Workshop & $\begin{array}{c}\text { Car } \\
\text { Repairing }\end{array}$ & $\begin{array}{c}\text { Metal } \\
\text { processing }\end{array}$ & $\begin{array}{c}\text { Wood } \\
\text { processing }\end{array}$ & $\begin{array}{c}\text { Car } \\
\text { Repairing }\end{array}$ & $\begin{array}{c}\text { Metal } \\
\text { processing }\end{array}$ & $\begin{array}{c}\text { Wood } \\
\text { processing }\end{array}$ \\
\hline Mean & 16.73 & 7.38 & 8.18 & 15.77 & 10.72 & 12.31 \\
\hline SD & 2.77 & 9.05 & 4.08 & 2.73 & 2.17 & 8.10 \\
\hline Range & 6.6 & 19.9 & 31.6 & 6.7 & 5.26 & 38.6 \\
\hline Min & 14.1 & 0 & 0 & 13.1 & 8.4 & 0 \\
\hline Max & 20.7 & 19.9 & 31.6 & 19.8 & 13.66 & 38.6 \\
\hline
\end{tabular}

Workers in elected workshops are at risk of exposed chemicals. Occupational exposure to a variety of chemical compounds such as carbon monoxide, nitrogen dioxide, sulfur dioxide, and benzene that may cause serious occupational diseases and these finding clarify the prevalence of different respiratory, skin, and neurological diseases among workers engaged in such industrial sectors and our results are in accordance with different recent studies dealing with effect of exposure to chemical pollutants $(8,9,11)$ Except for $\mathrm{NO}_{2}$, levels of the other three pollutants inside all exposed workshops showed higher value than those inside the control workshops. This refers to the affecting of workers inside these workshops by the emission source of these pollutants. ${ }^{(20)}$ This could be due to the affecting of the control workshops by the outdoor heavy traffic activities because of its location in the main street compared to the exposed workshops. (21)

The highest levels of the above three pollutants were found in wood processing exposed workshops because of the presence of other sources rather than the industrial operations such as heavy smoking activity inside the workplace $\operatorname{area.}^{(21)}$

Generally, levels of air pollutants during the evening periods are higher than levels of the morning periods. Most of activities in the selected workshops, particularly car 
repairing, occur at the evening time.(21)

In some cases, levels of the indoor levels of some air pollutants exceed the outdoor values, such as the high levels of benzene inside the car repairing workshops compared to the outdoor levels.

This can be explained by the temporary sources of these pollutants at different periods and conditions. For the same example, benzene is used inside the car repairing workshops for cleaning of the internal part of car motors. ${ }^{(22)}$

\section{CONCLUSION}

In conclusion, the workers at the studied industries were exposed to higher heat, noise, and illumination as well as higher levels of $\mathrm{CO}, \mathrm{SO} 2$, and $\mathrm{NO} 2$ than were experienced by the comparison areas. These findings should be used as a preventive measures for monitoring and application of control strategies in such workplace environment.

Acknowledgement: The authors thank Sultan Al-Qahtani graduate student from
College of Applied Medical Sciences, King Faisal University, who provided support in the field work,

\section{REFRENCES}

1. Shida,WU, Juan LU, Ping LIU, et al. The research on the occupational health for the small industries in Tao Pu District of Shanghai. J Labour Med. 1999;16 (3).

2. NThi-Hong-Tu. Occupational health and safety in small, medium-sized and informal sector enterprises in Vietnam.Asia -Pacific Newsletter on Occupational Health and Safety. 2003;10,7-10.

3. Parl HHE, Kim J, Jung H, Paek D. Occupational Health services for small-scale enterprises in Korea.Ind Health. 2002;40,1-6.

4. Bruce TF. Occupational safety and health, small-scale enterprise and employment. Afr Newslett on Occup Health and Safety 1990.

5. Injury, illness \& pollution prevention in auto repair, Occupational Health Branch, California: Department of Health Services; 2003.

6. U.S. EPA. 1991. Guides to Pollution, The Automotive Repair.

7. Encyclopaedia of Occupational Health and Safety, 4th Ed., ILO, Geneva, 1998, Vol. 2, p. 49.6, 49.17 (See also information on welding and welders in various chapters).

8. IARC. Wood Dust. IARC Monographs on the Evaluation of Carcinogenic Risk of Chemicals to Humans. Vol. 62. Lyon, France: International Agency for Research on Cancer; 1995. p. 35215.

9. Liou SH, Cheng SY, Lai FM, Yang JL. Respiratory symptoms and pulmonary function in mill workers exposed to 
wood dust. Am J Ind Med 1996; 30(3): 293-9.

10. www.Tes.com\TES-1352A/ TES 1336A

11. Gomes J, Lloyd 0, Norman J. Dust exposure and impairment of lung function at a small iron foundry in a rapidly developing country. Occup Environ Med. 2001; 58: 656-62.

12. Thermo Electron Corporation Environmental Instruments. MIRAN 205B Series Sapphlre Portable Ambient Air Analyzer. Instruction Manual, P/N BK3538, USA. www.thermo.com/eid. 2004

13. Ballal SG, Ahmed HO, and Sebiany AM. Occupational health in Saudi Arabia: occup Med. 2002 Jul-Sep ;17(3): 491- 507

14. Encyclopaedia of Occupational Health and Safety, 4th Ed. Geneva: ILO; 1998, Vol. 2, p. 49.6, 49.17

15. TLVs and BEls Threshold Limit Values for Chemical Substances and Physical Agents \& Biological Exposure Indices. Cincinnati: ACGIH; 2008.

16. Gomes J, Lloydt 0, Normant N. The health of the workers in a rapidly developing country: effects of occupational exposure to noise and heat Occup. Med. 2002; Vol.52 No.3, pp. $121-8$.

17. Milanowski J, Gora A, Skorska C, Krysinska-Traczyk E, Mackiewicz B, Sitkowska J, et al. Work-related symptoms among furniture factory workers in Lublin region (Eastern Poland). Ann Agric Environ Med 2002; 9(1): 99-103.

18. OSHA. Inspection narrative for OSHA inspection No. 100987551, Champion International Paper Company. U.S. Department of Labor, Occupational Safety and Health Administration, Augusta Area Office. Memorandum for Regional Administrator, February 12, 1991.

19. Awahl SH, Norman JN, Brebner JA. Heat cramps in a hot desert work-site. Kuwait MedJ. 2000; 32: 382-6.

20. Charles K, Magee RJ, Won D, Lusztyk E Indoor Air Quality Guidelines and Standards. National Research Council Canada, 2005:RR-204.

21. Kingdom of Saudi Arabia, Royal Commission For Jubail And Yanbu, Royal Commission Environmental Regulations; (2004), volume 1. 